\title{
The effect of rapeseed fed to suckled ewes on the fatty acid profile of lamb meat ${ }^{*}$
}

\author{
B. Borys ${ }^{1}$, J.J. Pająk ${ }^{2}$ and A. Borys ${ }^{3}$ \\ ${ }^{I}$ National Research Institute of Animal Production, Department of Animal Genetic and Breeding, \\ Experimental Station Koluda Wielka, 88-160 Janikowo, Poland \\ ${ }^{2}$ The Kielanowski Institute of Animal Physiology and Nutrition, Polish Academy of Sciences \\ 05-110 Jablonna, Poland \\ ${ }^{3}$ Meat and Fat Research Institute \\ Jubilerska 4, 04-190 Warszawa, Poland
}

\begin{abstract}
Two groups of 6 ewes suckling a single ram lamb were fed diets with $75 \%$ forage and $25 \%$ concentrate. In the experimental group, part of the concentrate was replaced by $150 \mathrm{~g}$ full-fat rapeseed. Lambs were slaughtered at 60 days of age and their M. adductor and M. semitendinosus were taken to determine chemical composition and fatty acid profile. The rapeseed supplement changed the fatty acid profile and increased the content of protein, fat and conjugated linoleic acid (CLA) in ewe milk. The changes in milk composition had a beneficial effect on the quality of lamb meat by reducing the content of intramuscular fat and increasing the proportion of unsaturated (UFA), polyunsaturated (PUFA) and $n-3$ fatty acids.
\end{abstract}

KEY WORDS: ewes, milk, rapeseed, suckling lambs, meat, fatty acids

\section{INTRODUCTION}

In recent years, considerable attention has been given to the possibility of modifying the composition of fatty acids in ruminant milk and meat to make them healthier for humans (Wiliams, 2000). The composition of a ruminant ration is one of the most important factors affecting the quantity, and above all, the quality of components deposited in intramuscular and depot fat of animals. Many recent studies (e.g., Scollan et al., 2001) determined the possibility of changing the proportion of saturated (SFA) to mono- (MUFA) and polyunsaturated fatty acids (PUFA), and increasing the proportion of CLA in the milk and meat of animals.

The present study was designed to determine the effect of supplementing rations of suckled ewes with rapeseed on the CLA content and fatty acid profile of milk, and

\footnotetext{
${ }^{*}$ This research was conducted as part of National Research Institute of Animal Production statutory activity, Project No. 2203.2

${ }^{1}$ Corresponding author: e-mail: izzzdkw@by.onet.pl
} 
on the CLA content and fatty acid profile of the meat of suckling lambs.

\section{MATERIAL AND METHODS}

Two groups of 6 ewes feeding a single ram lamb were fed diets of similar nutritional value containing $75 \%$ forage and $25 \%$ concentrate. In the experimental group $(\mathrm{R})$, part of concentrates was replaced by $150 \mathrm{~g}$ full-fat rapeseed. In both groups, lambs from 3 weeks of age were fed ad libitum with meadow hay and concentrate mixture.

Milk samples taken for 3 days at 8 weeks of lactation during morning and evening milking were analysed for DM, protein and fat using MilkoScan equipment, and for cholesterol content and fatty acid profile by gas chromatography.

Lambs were slaughtered at the age of 60 days at an average body weight of $19.6 \pm 4.1 \mathrm{~kg}$ and $M$. adductor and M. semitendinosus were taken for analysis. $M$. adductor was analysed for DM, protein and ether extract, and intramuscular fat extracted from $M$. semitendinosus for fatty acid profile and cholesterol content. The cholesterol content was determined using a HP 5890 sII gas chromatograph with an HP-1 column, and the fatty acid profile, using a HP 6890 chromatograph with an Rtx-2330 column (Kramer et al., 1997).

The results were analysed statistically using Statistica 6.0 PL software.

\section{RESULTS AND DISCUSSION}

The DM and protein content of milk was similar in both groups (Table 1). There was a small increase in the content of fat and cholesterol (by 8 and 7\%, respectively) and a marked increase in the content of CLA (by 35\%) in the milk of

Table 1. Ewe milk composition

\begin{tabular}{lcc}
\hline \multirow{2}{*}{ Composition } & \multicolumn{2}{c}{ Feeding group } \\
\cline { 2 - 3 } Chemical composition, $\mathrm{g} / 100 \mathrm{~g}$ of milk & $\mathrm{C}$ & $\mathrm{R}$ \\
dry matter & 16.20 & 16.75 \\
protein & 4.05 & 4.23 \\
fat & 6.27 & 6.75 \\
cholesterol, mg & 307.6 & 328.5 \\
CLA, mg & 50.1 & 67.5 \\
& & \\
Fatty acid profile of milk fat, g/100 g of fat & & \\
SFA & 68.80 & 61.55 \\
UFA & 28.73 & 35.74 \\
UFA/SFA & 0.42 & 0.58 \\
MUFA & 23.68 & 31.19 \\
PUFA & 5.05 & 4.55 \\
PUFA/SFA & 0.07 & 0.07 \\
n-3 & 1.20 & 1.40 \\
n-6:n-3 & 2.13 & 1.97 \\
CLA & 0.80 & 1.00 \\
\hline
\end{tabular}


ewes from group $\mathrm{R}$, which resulted from a greater proportion of this component in milk fat (by $25 \%$ ) than in group $\mathrm{C}$, and from its higher fat content.

Dietary supplementation of rapeseed caused distinct changes in the fatty acid profile of milk fat, which contained 11\% less SFA, 24\% more UFA, and a 39\% higher UFA: SFA ratio. Such an increase in the proportion of UFA was due mainly to the $32 \%$ higher proportion of MUFA, mainly oleic acid (C18:1), which is the main fat in rapeseed.

In the milk of sheep from group R, there was $10 \%$ less PUFA, with a similar PUFA:SFA ratio as in group C. In group R, $n-3$ PUFA increased by $17 \%$ and the $n-6: n-3$ ratio decreased by $8 \%$.

Considerable, although statistically non-significant differences were found in the composition of muscle tissue of lambs (Table 2). With similar contents of DM, protein and cholesterol, muscles of lambs from group $\mathrm{R}$ compared with $\mathrm{C}$ contained less fat and CLA, by 21 and $22 \%$, respectively. The non-significant differences in CLA content were due to the lower fatness of muscles of lambs from group R. Daily CLA consumption in milk was 332 and $482 \mathrm{mg}$ in the control and experimental group, respectively.

The proportion of CLA in intramuscular fat was similar in both groups. In an experiment by Szumacher-Strabel et al. (2004), a 4\% supplement of rapeseed oil to the diet of fattened lambs increased the CLA content by approximately $16 \%$.

More pronounced differences were observed in the fatty acid profile of intramuscular fat, especially in SFA and UFA, which increased the UFA:SFA ratio by $18 \%$ in group R. These data concur with the findings of SzumacherStrabel et al. (2004), in which the UFA content increased by approximately $5 \%$ and $n-3$ acids increased by approximately $40 \%$ in the intramuscular fat of lambs fed diets supplemented with rapeseed oil. The lower MUFA

Table 2. Chemical composition of lambs muscular tissue and fatty acid contents in intramuscular fat

\begin{tabular}{lrrr}
\hline \multirow{2}{*}{ Composition } & \multicolumn{2}{c}{ Feeding group $(\mathrm{n}=6)$} & \multirow{2}{*}{ SEM } \\
\cline { 2 - 3 } & \multicolumn{1}{c}{$\mathrm{C}$} & $\mathrm{R}$ & \\
\hline Muscular tissue components, g/100 g of tissue & & 23.24 & 0.20 \\
$\quad$ dry matter & 23.35 & 20.32 & 0.33 \\
protein & 19.33 & 2.59 & 0.20 \\
fat & 3.26 & 63.82 & 1.86 \\
cholesterol, mg & 12.43 & 10.00 & 1.24 \\
CLA, mg & & & \\
Fatty acids, g/100 g of intramuscular fat & 45.05 & 41.13 & 1.03 \\
SFA & 53.78 & 57.62 & 1.02 \\
UFA & 1.20 & 1.42 & 0.06 \\
UFA:SFA & 38.50 & 36.95 & 0.59 \\
MUFA & 15.28 & 20.67 & 1.48 \\
PUFA & 0.34 & 0.52 & 0.05 \\
PUFA:SFA & 2.85 & 3.75 & 0.27 \\
n-3 & 4.12 & 4.28 & 0.10 \\
n-6:n-3 & 0.40 & 0.40 & 0.03 \\
CLA & & &
\end{tabular}

$\overline{\mathrm{SEM}}$ - standard error mean 
content in group R and the markedly higher PUFA content (by 35\%) resulted in a $50 \%$ higher PUFA:SFA ratio and a $32 \%$ greater content of $n-3$ PUFA.

The differences found in the fatty acid composition and profile in milk of ewes and in muscle tissue of lambs were more pronounced in the current experiment when ewes were supplemented with rapeseed than in the studies of Borys et al. (2005) when linseed and rapeseed were added.

\section{CONCLUSIONS}

It was found that the use of full-fat rapeseed in the feeding of suckled ewes altered the chemical composition and fatty acid profile of milk. The changed milk composition has a favourable effect on the meat quality of suckling lambs by lowering muscle fatness and by changing the fatty acid profile of intramuscular fat through increasing SFA, PUFA and $n-3$ acids.

\section{REFERENCES}

Borys B., Borys A., Pająk J., 2005. The fatty acid profile of meat of suckling lambs from ewes fed rapeseed and linseed. J. Anim. Feed Sci. 14, Suppl. 1, 223-226

Kramer J.C.K., Fellner V., Dugan M.E.R., Sauer F.D., Mossoba M.M., Yurawecz M.P., 1997. Evaluation acid and base catalysts in the methylation of milk and rumen fatty acids with special emphasis on conjugated dienes and total trans fatty acids. Lipids 32, 1219-1228

Scollan N.D., Choi N.-J., Kurt E., Fisher A.V., Enser M., Wood J.D., 2001. Manipulating the fatty acid composition of muscle and adipose tissue in beef cattle. Brit. J. Nutr. 85,115-124

Szumacher-Strabel M., Potkański A., Cieślak A., Kowalczyk J., Czauderna M., 2004. Effect of adding fat to the diet for lambs on the fatty acid profile of intramuscular, perirenal and subcutaneous fat. J. Anim. Feed Sci. 13, Suppl. 1, 355-358

Williams C.M., 2000. Dietary fatty acids and human health. Ann. Zootech. 49, 165-180

\section{STRESZCZENIE}

Wpływ nasion rzepaku w dawkach dla matek karmiących na profil kwasów thuszczowych mięsa jagniąt

Dwie grupy po 6 matek karmiących jedynaka tryczka żywiono dawkami o podobnej zawartości białka i energii. W grupie doświadczalnej część paszy treściwej zastąpiono $150 \mathrm{~g}$ nasion rzepaku. Jagnięta ssące ubito w 60 dniu życia i pobrano mięśnie udźca do oznaczenia składu chemicznego i profilu kwasów tłuszczowych. Stwierdzono, że dodatek nasion rzepaku powoduje zmianę profilu kwasów thuszczowych oraz wzrost zawartości białka, tłuszczu, a zwłaszcza CLA, w mleku matek. Zmiana składu mleka korzystnie wpłynęła na jakość mięsa jagniąt, poprzez zmniejszenie zawartości tłuszczu śródmięśniowego oraz zmianę profilu jego kwasów tłuszczowych - zwiększenie udziału kwasów nienasyconych i wielonienasyconych oraz z grupy n-3. 